\title{
A ZENEI AGY: TANULÁS ÉS MEMÓRIA
}

\section{THE MUSICAL BRAIN: LEARNING AND MEMORY}

\author{
Katie Overy \\ PhD, egyetemi tanár, igazgató, Institute for Music in Human and Social Development (IMHSD), Reid School of Music, \\ Edinburgh College of Art, University of Edinburgh, UK \\ k.overy@ed.ac.uk
}

\begin{abstract}
ÖSSZEFOGLALÁS
A zenélés és zenehallgatás olyan örömteli cselekvés, amely évszázadok óta magával ragadja az emberi szíveket és az értelmet. A zenetanárok szerint a zenetanulásnak számos előnye lehet a személyiségfejlődésben, a társas kapcsolatok megélésében, a kulturális élmények értő befogadásában. A zenét tanulók iskolai teljesítménye is jobb, mint azoké, akik nem tanulnak zenét. Az alább bemutatandó kutatások a pszichológia és idegtudomány területeiről feltárták azokat az agyterületeket, amelyek kapcsolatban állnak a zenei inger feldolgozásával, és igazolták a zenei tréning hatását az agy működésére és szerkezetére.

Tanulmányomban először bemutatom az ún. „örömteli zenei viselkedés” jellemzőit és ezek jelentőségét az emberi fejlődésben, különösen gyermekkorban. Ezt követi a zenei feldolgozás idegi alapjairól szóló néhány fontos kutatási eredmény ismertetése a zenei tréning hatásáról az agyszerkezetre és -működésre. A tanulmány következő részének témája a tanulás és a memória, különösen a nyelv és a motoros készségek. Majd az Edinburghi Egyetem Reid Zenemúvészeti Karán működő Zene az Egyéni és Társas Fejlődésben Intézet keretei között lefolytatott négy kísérletet ismertetek, amelyek mindegyike a zenetanulás más-más aspektusát vizsgálta.
\end{abstract}

\section{ABSTRACT}

Human musical behaviour is a joyous activity that has captivated hearts and minds for centuries. Music educators have often claimed that musical learning can have a range of benefits for children, from increased personal and social well-being to enhanced cultural understanding and even academic achievement. Recent experimental studies in the fields of psychology and neuroscience are beginning to add weight to such claims, with a growing body of research identifying the full extent to which the brain engages with musical stimuli, and the potential effects of musical training on brain functions and structure. In this paper, I will begin by discussing the joyfulness of musical behaviour and its relevance in human experience, particularly during childhood. This will be followed by a summary of recent research findings on the neural basis of musical processing and evidence that musical training can affect certain aspects of brain function and structure. The focus of this part of the study will be on learning and memory, and

\footnotetext{
${ }^{1}$ Fordította Csontos Tamás és Papp Lilla.
} 
specifically on language and motor skills. I will then outline four different experimental studies conducted in the Institute for Music in Human and Social Development at the University of Edinburgh, each of which investigated a different aspect of musical learning.

Kulcsszavak: zenepedagógia, agykutatás, memória, tanulás

Keywords: music education, brain research, memory, learning

Az Edinburghi Egyetem Reid Zenemüvészeti Karán működő Zene az Egyéni és Társas Fejlődésben Intézet (Institute for Music in Human and Social Development, IMHSD) keretei között lefolytatott négy kísérlet közül az elsőben (Ludke et al., 2014) hatvan angol anyanyelvű felnőttet vizsgáltak, és először szereztek adatokat arra vonatkozóan, hogy az éneklés serkentheti a kifejezéspárok tanulását idegen nyelven. A résztvevőket véletlenszerủen társították az egyikhez a három ún. hallgatás és ismétlés tanulási helyzethez: a beszédhez, a ritmikus beszédhez és az énekléshez. A résztvevőknek ezután húsz magyar kifejezést mutattak, amit 15 perc alatt kellett megtanulniuk. Az éneklési tanulási helyzetben részt vevők a tanulási periódus után jobb összteljesítményt nyújtottak a magyar nyelvi teszteken, mint a másik két tréning részvevői. Ezt a magasabb teljesítményt statisztikailag szignifikánsnak találták annál a két tesztnél, ahol a résztvevőknek viszsza kellett emlékezniük magyar kifejezésekre, majd elő kellett azokat hívniuk. Számos további mérés megerősítette, hogy a teljesítménybeli különbségeket nem magyarázhatják olyan háttértényezők, mint a kor, a nem, a hangulat, a fonológiai memória vagy a zenei képesség és képzettség. Ezek az eredmények arra utalnak, hogy a hallgatás és éneklés tanulási módszer fejlesztheti az ún. szópárosító memóriát idegen nyelvü kifejezések esetében. Ezt az eredményt alátámasztják azoknak a tanulóknak a tapasztalatai is, akik az idegen nyelvü szavakat dalokon keresztül sajátítják el.

A második kutatás (Moore et al., megjelenés alatt) egy fMRI-vizsgálati módszert használó kísérlet, amelybe szintén felnőtteket vontak be. A kutatók feltételezték, hogy egy zenei, hallási-mozgásos tanulási feladat, melyet bal kézzel kell elvégezni, mikrostrukturális neuroplaszticitáshoz vezet a jobb fasciculus arcuatusban. (Ez egy fehérállomány, amely az agy hallási és motoros régióit köti össze.) Harminc jobbkezes résztvevő vett részt a mozgásos tanulási kísérletben. Az egyik csoport zenei segítséget kapott, míg a kontrollcsoport nem. A résztvevők húszperces mozgásos gyakorlatot végeztek el hetente háromszor, négy héten keresztül, ami így összesen négyórás gyakorlati időt tett ki. Diffúziós tenzor MRI-t és probabilista szomszédos taktográfiát felhasználva azonosították a frakcionális anizotróp (FA), az axiális és radiális diffuzivitási átlagértékeket a jobb és a bal fasciculus arcuatusban minden egyes résztvevőnél a négyhetes periódus előtt és után. Az FA 
a vízmolekula diffúzió koherenciájának irányát méri, és gyakran használják arra, hogy információt nyerjenek a fehérállomány szerkezetéről és az idegi kacsolódásról. Az axiális és radiális diffuzivitás a víz diffúzió nagyságát méri az elsődleges rostirányra párhuzamosan és merőlegesen. Ezeket a paramétereket együtt fel lehet használni a mielinizáció és az axonális membránintegritás meghatározására. Az eredmények szerint csak a zenei csoportnál növekedik szignifikánsan az FA a jobb kontralaterális fasciculus arcuatusban, és amint feltételezték, az AD (axiális diffuzivitás) növekedett, míg az RD (radiális diffuzivitás) csökkent. Az előzetes várakozásoknak megfelelően, a bal ipszilaterális fasciculus arcuatusban nem találtak szignifikáns változásokat egyik csoportnál sem. Ezek az eredmények megegyeznek az aktivitásfüggő növekedésekkel a mielinizáció folyamatában. Ez az első bizonyíték arra, hogy a mozgástanuláshoz zenei segítséget hozzáadva, gyors mikrosktruktúrális változást lehet indukálni a felnőtt agy fehérállomány pályáiban. Ezek az eredmények fontos útmutatások ahhoz, hogy megértsük, a zene hogyan használható fel a mozgástanulás elösegítésére rehabilitációs környezetben, $\mathrm{s}$ azt is bizonyítják, hogy a zenélés hatással lehet az agy szerkezetére.

A harmadik kutatást (Almeida et al., 2017) óvodásokkal végezték el. A cél az volt, hogy betekintést nyerjenek abba, hogy egy fejlödő gyermek hogyan reagál zenei ütemekre egy olyan helyzetben, amikor a mozgását nem szabályozza elözetesen elöírt koreográfia. A tanulmány középpontjában a szenzorimotoros szinkronizáció (SMS) áll, amit általában azzal szoktak vizsgálni, hogy a résztvevők milyen pontosan tudnak ujjal koppintani auditív ingerre. A most ismertetett kísérletsorozat célja az volt, hogy megismerje, milyen mozdulatokat hív elő egy zenei ütem a kisgyermekekböl. 45 négy és öt év közötti gyereket kértek meg arra, hogy az úgynevezett „Ana játékot” játsszák, amelyben úgy mozoghattak, ahogyan akartak, miközben 30 másodperces ritmikus, szinkópát tartalmazó zenét hallgattak, különböző sebességgel lejátszva. Minden résztvevőt videóra vettek, és a Laban-mozgáskottával dokumentálták, hogy milyen mozgásokkal válaszoltak a zenére. Az eredmények azt mutatták, hogy feltünően sokféle mozdulatot tettek, a lábfejük ütögetésétől a riszáláson és ugrándozáson át a futkorászásig. Ráadásul minden gyermeknek megvolt a kedvenc mozdulata, és a legtöbb gyermek a kísérlet során kitartott e mozdulata mellett, örömteli és játékos érzelemkitörésekkel kísérve mozgását. Végezetül minden mozdulat erős, kétfázisú, periodikus mozgást mutatott, amely tükrözte a zene mélyszerkezeti jellemzőit és a tempóváltozásokat is, de ritkán követte pontosan az ütemet. Ezek az eredmények azt sugallják, hogy a kicsi gyermekek számára, akik egyedi testi és motoros fejlődésen mennek keresztül, a zenére válaszul adott mozdulat szabad kiválasztása sokkal hatásosabb és jelentőségteljesebb élmény, mint egy előírt koreográfia megvalósítása, amely pontos ritmikai időzítést igényel.

A negyedik kutatásban (Moore et al., előkészületben) hét és tizenegy év közötti diszlexiás gyermekek vettek részt. A kutatás célja az auditív-motoros szinkroni- 
zációs képességek lehetséges szerepének feltárása a zenei gyakorlás és a nyelvi és olvasási képességek transzferfolyamatában. Harminc diszlexiás gyermeket két különböző iskolából véletlenszerüen választottak ki vagy a Kodály-koncepciót követő és aktív ritmusjátékokon alapuló Zenei Tevékenység Programra (MAP, vö. Overy, 2008), vagy a Zenehallgatási Programra (MLP). Mindkét zenei programra hetente háromszor került sor az iskolákban, tizenöt héten keresztül, és mindegyik alkalom húsz percig tartott. A zenei beavatkozások elött és után az összes gyermek zenei, fonológiai és olvasási készségét is megmérték. A hipotézis az volt, hogy a gyerekek a MAP-csoportban a ritmikus motoros készségeket, a fonológiai szegmentációs készségeket és olvasási készségeket igénylö feladatokban jobban teljesítenek az MLP-csoportnál. Az eredmények ezt a feltételezést megerősítették: a MAP-csoport tagjai az olvasás, a helyesírás és szóolvasás terén szignifikánsan jobban fejlödtek az MLP-csoportnál. A MAP-csoport a ritmusmásolás és fonológiai szegmentáció terén jelentős fejlődést mutatott. Mindkét csoport fejlődött a ritmusmegkülönböztetésben. Ezek az eredmények az első bizonyítékai a zenei gyakorlás egyes típusai nyelvi és olvasási készségekre vonatkozó sajátos hatásának, és azt is jelzik, hogy a ritmusalapú auditív-motoros tevékenységek különösen hasznosak diszlexiás gyerekek esetében.

Az itt röviden bemutatott kutatások egy nagyobb kutatási területbe nyújtanak betekintést. A zenei élmény gazdag és komplex természetét nem lehet egyetlen kísérlettel megragadni, de egyéni és kismintás kutatásokat érdemes és lehetséges is megtervezni és végrehajtani ezen a területen. A további kutatómunka bepillantást adhat a zenei viselkedésbe, és megmutatja, hogy a zenei tanulás és memória hatással vannak az emberi intelligencia különbözö területeire. Mivel az agyat feltérképező technológiák (EEG, MRI, DT-MRI és TMS) gyorsan fejlődnek, egyre több kutatás születik, melyek a zenei agy jobb megértésére irányulnak.

\section{KÖSZÖNETNYILVÁNÍTÁS}

Köszönöm valamennyi önkéntesnek, hogy részt vettek a vizsgálatokban, továbbá külön köszönöm Vendrei Éva és a néhai Kokas Klára inspirációit.

\section{IRODALOM}

Almeida, A. - Miell, D. - Overy, K. (2017): Playing with the Beat: A Process-oriented Approach to Studying Sensorimotor Synchronization in Early Childhood. In: Lessafre, M. - Leman, M. Maes, P-J. (eds.): The Routledge Companion to Embodied Music Interaction. Routledge, https:// bit.ly/2H4gZLN

Bigand, E. - Tillmann, B. - Peretz, I. et al. (eds.) (2015): The Neurosciences and Music V: Cognitive Stimulation and Rehabilitation. Annals of the New York Academy of Sciences, 1337. 
Ludke, K. - Ferreira, F. - Overy, K. (2014): Singing Can Facilitate Foreign Language Learning. Memory and Cognition, 42, 1, 41-52. DOI: 10.3758/s13421-013-0342-5, https://www.researchgate.net/publication/249966411_Singing_can_facilitate_foreign_language_learning

Moore, E. - Branigan, H. - Overy, K. (in preparation): Multisensory Rhythm-based Musical Games Support Literacy Skills in Children with Dyslexia.

Moore, E. - Schaefer, R. - Bastin, M. et al. (2017): Diffusion Tensor MRI Tractography Reveals Increased Fractional Anisotropy in Arcuate Fasciculus Following Music-cued Motor Training. Brain and Cognition, 116, 40-46. DOI: 10.1016/j.bandc.2017.05.001, https://www.sciencedirect. com/science/article/pii/S0278262617300210?via\%3Dihub

Overy, K. (2008): Classroom Rhythm Games for Literacy Support. In: Westcombe, J. - Miles, T. - Ditchfield, D. (eds): Music and Dyslexia: A Positive Approach. Wiley, 151-161. DOI: 10.1002/9780470988183.ch4, https://www.researchgate.net/publication/228050605_Classroom_ Rhythm_Games_for_Literacy_Support

Overy, K. (2012): Making Music in a Group: Synchronisation and Shared Experience. Annals of the New York Academy of Sciences, 1252, 65-68. DOI: 10.1111/j.1749-6632.2012.06530.x, https://pdfs.semanticscholar.org/f708/94c238ba51196c4a3b71c10313b4b0b7b134.pdf

Overy, K. - Lopez, L. - Majno, M. et al. (eds.) (2012): The Neurosciences and Music IV: Learning and Memory. Annals of the New York Academy of Sciences, 1252. 